\title{
Implementation of Distribution Requirement Planning in the Subsidized Fertilizer Management System
}

\author{
Alvina DAYANTI ${ }^{1}$, Mgs. Afriyan FIRDAUS ${ }^{2 *}$, Allsela MEIRIZA ${ }^{3}$, Dwi Rosa \\ INDAH $^{4}$, and Ahmad HERYANTO ${ }^{5}$
}

\author{
1,2,3,4 Information System Department, Faculty of Computer Science, Universitas Sriwijaya, Indonesia \\ ${ }^{5}$ Computer System Department, Faculty of Computer Science, Universitas Sriwijaya, Indonesia \\ *Corresponding author: afriyan_firdaus@unsri.ac.id
}

\begin{abstract}
Food security is one of the Indonesian government's strategic programs. In support of the Food Security Program, the Ministry of Agriculture has established a policy on the distribution of subsidized fertilizer needs, especially for food crops, which are six right policies. Subsidized fertilizer distribution planning is very important to support the achievement of the six right policies because proper distribution planning will result in meeting the needs of farmers for fertilizer. Distribution Requirement Planning (DRP) method is used to determine the planning needs and it is expected that with the distribution pattern, good marketing stock, success in meeting the needs of the fertilizer stock inventory will be more optimal. In this paper, the DRP method will be used to optimize the role of subsidized fertilizer management systems. The case study for this paper is the warehouses of PT. Pupuk Sriwidjaja Palembang, namely PPD Sumsel, while the type of subsidized fertilizer that will become the scope is urea fertilizer. From this study can be concluded that the DRP method provides a more coordinated distribution reference for urea subsidized fertilizer. With the distribution schedule, the company can prepare everything so that it can distribute products. Moreover, the implementation of DRP in the subsidized fertilizer data management system is used to optimize existing data collection and reporting functions, by adding feature requirements according to the DRP concept such as fertilizer management of stock, demand and distribution, safety stock and DRP calculation, also fertilizer report for a company manager.
\end{abstract}

Keywords: Distribution Requirement Planning, management system, subsidized fertilizer

\section{Introduction}

Food security is one of the Indonesian government's strategic programs. It is illustrated by several regulations and policies governing national food security and the establishment of the Food Security Agency. Several studies have also discussed matters related to food security, including discussing the concept, measurement, and strategy [1], problems and challenges [2], strategies for improving the household [3], and the knowledge management of village granary management [4].

In support of the Food Security Program, the Ministry of Agriculture has established a policy on the distribution of subsidized fertilizer needs, especially for food crops, which are six right policies: right quantity, right time, the right type, right price, right place, and right quality. Subsidized fertilizer distribution planning is very important to support the achievement of the six right policies because proper distribution planning will result in meeting the needs of farmers for fertilizer to achieve food security.

Regarding distribution planning, the concept of Distribution Requirement Planning (DRP) is introduced like a system that determines the demand for supplies for distribution centers, combines historical demand, and as inputs for production and materials [5]. Meanwhile, DRP is a planning approach that is almost the same as MRP that uses demand planning at the point of need to determine demand forecasting to the center [6]. It is even said that DRP is very important in the global market [7]. From this opinion, it can be concluded that DRP is a system that determines the planning needs to replenish inventory at the distribution center. DRP provides future demand visibility related to the need for shipping from source stocking points to destination stocking points. This will help to take corrective actions taken before undesirable events develop into crises [8].

A computer-based system is needed to optimize information management [13] in supporting food security, in this case, data related to the number of food products [12], stock availability, and other materials that support food availability, such as fertilizer. Fertilizer is one of the important production factors in agricultural cultivation. Various fertilizer distribution policies issued by the government so far generally aim to further improve efficiency in distribution. However, in reality, there are still many cases of fertilizer scarcity, where farmers have difficulty getting fertilizer when they need it [9]. The enhancement of fertilizer subsidies is one of the backbones of agricultural policy since 1969. Along with various problems and negative impacts of these policies, it is noted to continue the policy of fertilizer subsidies by improving planning, monitoring, distribution systems, and empowering extension agents [10].

Therefore, the DRP method is used in determining the planning needs [11] and it is expected that with the distribution pattern, good marketing stock, success in 
Application of the DRP method in management the subsidized fertilizer for PPD Sumsel is as follows:

1. Demand Forecasting

Demand forecasting is done to estimate the amount of Urea fertilizer demand in the future. This forecast uses urea fertilizer stock data from October 2018 to February 2019 (shown in Table 1. This method will produce forecasting data as well as gross requirements, which will be included in the DRP framework.

\section{Distribution Requirement Planning Method in The Subsidized Fertilizer}

Table 1. Subsidized UREA Fertilizer Data for October 2018 to February 2019

\begin{tabular}{|c|c|c|c|c|c|c|c|c|c|c|}
\hline Year & Month & $\begin{array}{c}\text { GPP } \\
\text { Naskah }\end{array}$ & $\begin{array}{c}\text { Tj. Api- } \\
\text { api }\end{array}$ & $\begin{array}{c}\text { DS. } \\
\text { Komplek } \\
\text { Pusri }\end{array}$ & $\begin{array}{c}\text { GPP } \\
\text { Martapura }\end{array}$ & $\begin{array}{c}\text { GD. } \\
\text { Belitang } \\
\text { MP }\end{array}$ & $\begin{array}{c}\text { GD. Lubuk } \\
\text { Linggau }\end{array}$ & $\begin{array}{c}\text { GD } \\
\text { Lahat }\end{array}$ & $\begin{array}{c}\text { GD. } \\
\text { OKI }\end{array}$ & $\begin{array}{c}\text { GD. } \\
\text { Prabu- } \\
\text { mulih }\end{array}$ \\
\hline \multirow{2}{*}{2018} & October & 196 & 39 & 675 & 733 & 714 & - & 202 & - & - \\
\cline { 2 - 11 } & November & - & 776 & - & 1077 & 942 & 40 & 160 & - & - \\
\cline { 2 - 11 } & December & - & - & - & 455 & 180 & 0 & 4 & - & - \\
\hline \multirow{2}{*}{2019} & January & - & 1594 & 196 & 1112 & 275 & 271 & 384 & - & - \\
\cline { 2 - 11 } & February & - & 274 & 1455 & 1313 & 423 & 264 & 441 & 138 & - \\
\cline { 2 - 11 } & March & - & - & - & - & - & - & - & - & - \\
\hline
\end{tabular}

Source: Distribution and Marketing Division PPD Sumsel

Based on the data in Table 1, inventory forecasting is done using Single Moving Average (SMA) forecasting method with the following formula:

$$
\begin{aligned}
& \mathrm{MA}=\frac{f \mathrm{t}-1+f \mathrm{t}-2+f \mathrm{t}-3+\ldots .+f \mathrm{t}-\mathrm{m}}{\mathrm{M}} \\
& \mathrm{MA}=\frac{196+0+0+0+0}{5}=39
\end{aligned}
$$

where:

MA = Moving Average

$f_{\mathrm{t}-1}=$ sales data per period

$\mathrm{m}=$ number of periods included
The result of demand forecasting with the simple moving average method is 39 for Urea in October 2018, where the results of this forecasting will be used as Gross requirements in the DRP calculation table.

\section{Determination of the Lead time}

The lead time used is for each warehouse. This determination is based on company policy. PPD Sumsel determined the delivery time is one month in one shipment. The shipment contained two types of fertilizer. One month is the longest period to cover the entire shipping area. This time is when the fertilizer has arrived and is received by the head of the warehouse.

Table 2. Warehouse Lead Time

\begin{tabular}{|l|l|}
\hline Warehouse Name & Lead Time \\
\hline GPP Naskah & 1 month \\
\hline Tj.Api-api & 1 month \\
\hline DS.Komp Pusri & 1 month \\
\hline GPP Martapura & 1 month \\
\hline GD Belitang MP & 1 month \\
\hline GPP LubukLinggau & 1 month \\
\hline
\end{tabular}




\begin{tabular}{|l|l|}
\hline Gd Lahat & 1 month \\
\hline GD. OKI & 1 month \\
\hline Gd Prabumulih & 1 month \\
\hline
\end{tabular}

Source: Distribution and Marketing Division PPD Sumsel

\section{Determination of Lot Size}

The lot Sizing technique used is Lot for Lot (LFL). This LFL technique is the simplest and easiest to understand the lot-sizing technique. Orders are made with consideration of minimizing the cost of saving. In this technique, the fulfillment of the net need $(\mathrm{NR})$ is carried out in each period that needs it, while the size of the order quantity (lot size) is the same as the amount of the net need (NR) that must be met in the relevant period.

This stage shows the lot size when ordering. Order fertilizer from the factory to the warehouse using boxcar transportation. Determination is based on the average delivery that occurs in the company.

4. Calculation of safety stock

To calculate safety stock, standard deviation data is needed which is calculated based on the amount of initial supply of subsidized fertilizer at each warehouse. The amount of initial inventory (Inventory On Hand) for each period at each level of distribution is not the same, depending on the magnitude of fluctuations in demand that occur and the smoothness of order arrivals and the smooth production process that takes place. The initial inventory level of a period is determined based on the end of the previous period.

Table 3. Inventory On Hand for February 2019

\begin{tabular}{|c|c|}
\hline PPD Sumsel & Number of Urea Fertilizer (Unit) \\
\hline GPP Naskah & 620 \\
\hline Tj. Api-api & 1079 \\
\hline DS Komp Pusri & 3158 \\
\hline GP Martapura & 3408 \\
\hline GD. Belitang MP & 3644 \\
\hline GPP Lubuk Linggau & 2314 \\
\hline GD Lahat & 1679 \\
\hline GD OKI & 2540 \\
\hline GD Prabumulih & 600 \\
\hline
\end{tabular}

After obtaining the results of the calculation of gross needs with a Single Moving Average, then a standard deviation is calculated to calculate the safety stock later.

$$
\text { STDEV }=\frac{\sqrt{\Sigma\left({\left.\mathrm{d}-\mathrm{d}^{\prime}\right)^{2}}^{2}\right.}}{\mathrm{n}} \quad=31
$$

where:

$\mathrm{d}$ : actual request

d': average requirement

$\mathrm{n}$ : number of periods included

In this study, it is assumed that the level of service desired by companies and agents is the same, namely $95 \%$. This service level is measured in several ways:

- Percentage of satisfaction of order fulfillment from stock

- Percentage of total requests sent from stock

- Percentage of the number of requests sent on time

- Percentage of time stock availability

- Percentage of stock fulfillment cycle without shortages

Lead Time $=1$

SS $($ Safety Stock $)=Z$ x s x 1

$$
=1,64 \times 31 \times 1=51,5
$$

$\mathrm{Z}=$ service level $95 \%=1,64$

$\mathrm{S}=$ Deviation Standard

$1=$ lead time

From the calculations that have been carried out obtained safety stock is 51.5 .

5. Reorder Point (ROP)

Reorder Point is the point where the distributor has to reorder so that the receipt of ordered fertilizer can be on time. Because making a fertilizer order cannot be accepted immediately that day. A large amount of fertilizer available is still available until the distributor places an order again at the calculated ROP.

$\mathrm{ROP}=$ Safety Stock $+($ Lead time $\mathrm{x}$ average requirement $)$

$$
=52+(1 \times 39)=91
$$

The ROP for urea fertilizer is 91 . Then in October 2018, the company will reorder when the inventory reaches the calculated ROP limit for each.

\section{Making DRP}

The basic logic of DRP calculation is as follows:

a. Gross Requirements/Forecast Demand is obtained from forecasting results. Value for forecasting for 12 months. Gross Requirements shows the number of requests for each

where: 
fertilizer based on the results of forecasting that have been done before that can be seen in table 4 .

b. From the results of local distribution forecasting, calculate the Time Phased Net Requirements. At this stage, the net requirements show the number of goods needed to meet the shortcomings in the existing demand. Then the number of products needed by each store will be shown to place an order at the warehouse at a certain time. Previously you need to know the project on hand, that is the number of items in inventory. Then the number of items is the number of each product in each store at the end of each month, in this case, shown in Table 4

Table 4. Projected on hand

\begin{tabular}{|c|c|}
\hline PPD Sumsel & Fertilizer stock (Unit) \\
\hline GPP Naskah & 620 \\
\hline Tj. Api-api & 1079 \\
\hline DS Komp Pusri & 3158 \\
\hline GP Martapura & 3408 \\
\hline GD. Belitang MP & 3644 \\
\hline GPP Lubuk Linggau & 2314 \\
\hline GD Lahat & 1679 \\
\hline GD OKI & 2540 \\
\hline GD Prabumulih & 600 \\
\hline
\end{tabular}

Then by knowing the project on hand, it can be calculated net requirements through reduction with gross requirements. Net requirements indicate the actual amount needed by each warehouse in each period.

For a period in Urea fertilizer:

Net Requirement $=($ Gross Requirement + Safety Stock (Projected On Hand last Period) (5)

NR Nov $=(39+91-(561)=431$

The Net Requirement value recorded is positive c. After that, a Planned order receipt of several Net Requirements was generated during this period. The amount of fertilizer to be ordered is seen from the Net Requirements and adjusted according to the size that has been set.

NR Nov $=470$ then $P O R=470$ d. Determined the day in which the order must be made (Planned Order Release) using the scheduled day Planned Order Receipt with Lead Time

e. Calculated Projected On Hand (POH) for the period: $\mathrm{POH}=(\mathrm{POH}$ Previous Period + Order Receipt $)-($ Gross Requirements)

Nov $\mathrm{POH}=(561+431)-91=901$

f. The amount of the Planned Order Release becomes a Gross Requirement in the same period for the next level of the distribution network

Analysis of DRP Implementation

The DRP method provides a more coordinated distribution reference for each product. With the distribution schedule, the company can prepare everything so that it can distribute products.

Table 5. Calculation Results of Urea fertilizer DRP

\begin{tabular}{|c|c|c|c|c|c|c|c|c|}
\hline \multirow[t]{3}{*}{$\begin{array}{ll}\text { On Hand Balance: } & 31 \\
\text { Safety Stock } & : 52\end{array}$} & \multicolumn{4}{|c|}{ Lead Time } & \multicolumn{3}{|c|}{$: 1$} & \\
\hline & \multirow{2}{*}{$\begin{array}{l}\text { Past } \\
\text { Due }\end{array}$} & \multicolumn{7}{|c|}{ Period } \\
\hline & & 1 & 2 & 3 & 5 & 6 & 7 & 8 \\
\hline Gross Requirement & & 39 & & & & & & \\
\hline Projected On Hand & 620 & 581 & & & & & & \\
\hline Net Requirements & & 0 & & & & & & \\
\hline Planned Order Receipts & & 0 & & & & & & \\
\hline Planned Order Release & & 0 & & & & & & \\
\hline
\end{tabular}




\section{Implementation of DRP in the Subsidized Fertilizer Management System}

The application of DRP in the subsidized fertilizer data management system is used to optimize existing data collection and reporting functions, by adding feature requirements according to the DRP concept as follows:

1. Fertilizer stock management

The fertilizer stock displays a table of inventory data contents per period where the distributor can see according to the selected year. Besides, distributors can also process inventory data, i.e. amend or delete incompatible data. The system display for the fertilizer stock page is shown in Figure 1.

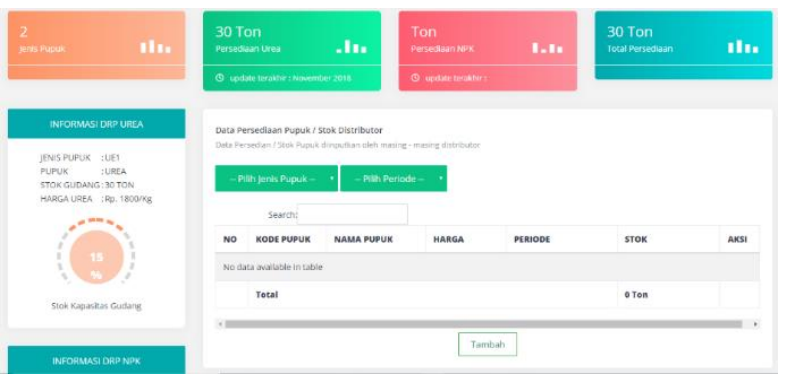

Figure 1. Display of fertilizer stock page

\section{Fertilizer demand management}

The fertilizer demand page is a page where distributors can enter, view and manage demand data by entering the attached file and the inventory amount shown in Figure 2.

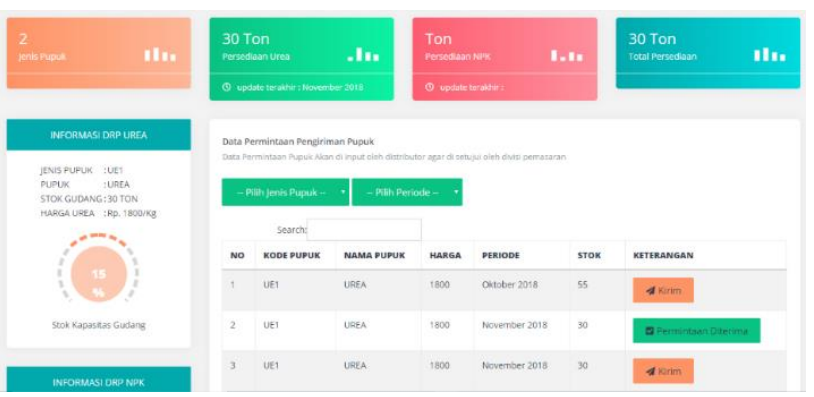

Figure 2. Display of fertilizer demand

\section{Fertilizer distribution management}

The fertilizer distribution processing page is a page that can display the total fertilizer to be distributed where the marketing staff confirms the distribution on request and the attachment attached by the distributor. The appearance of the fertilizer distribution processing page is shown in Figure 3.
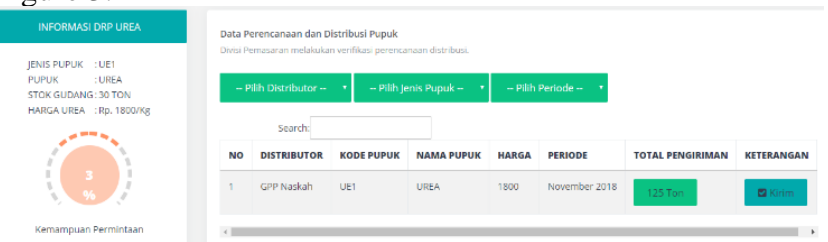

\section{Safety Stock Calculation}

The safety stock data calculation page is used to determine the amount of safety stock where the safety stock calculation results are obtained from the DRP method, namely the large number of stocks and the average demand for fertilizer stock divided by the number of fertilizer stock periods in the Distribution \& Marketing Division of PPD Sumsel. The safety stock calculation page is shown in Figure 4.

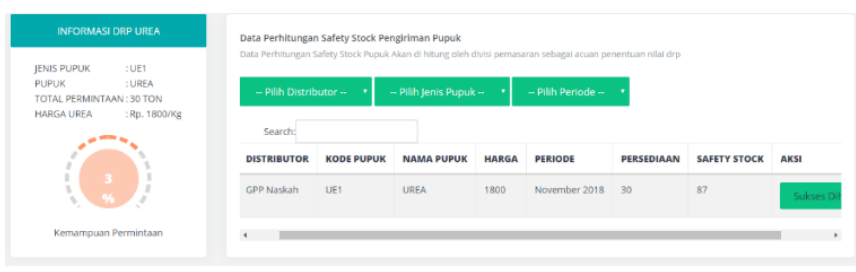

Figure 4. Display of Safety stock calculation

\section{DRP calculation}

DRP calculation page displays a table containing the DRP calculation data per period where the distributor can see the data table displayed according to the period and type of fertilizer selected. The DRP table data page also displays a table that contains an explanation of the amount of Safety stock, Lead time, Past Due, Net Requirements, POH type of fertilizer per period.

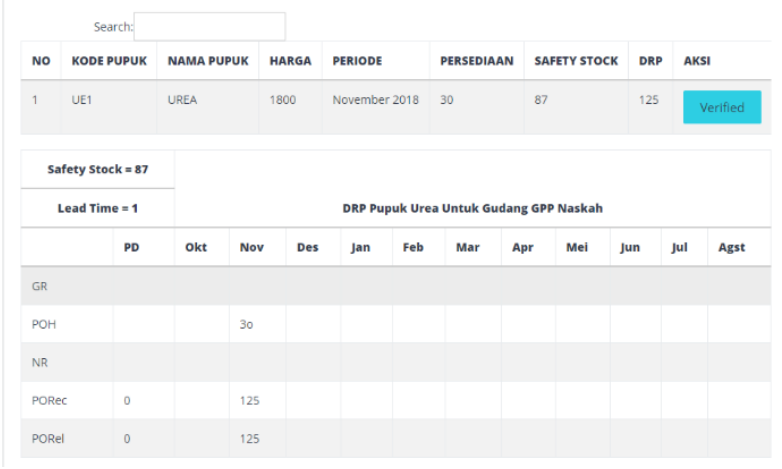

Figure 5. Display of DRP calculation

Besides, this DRP calculation is also used to calculate demand and safety stock data from distributors. If the inputted data has been calculated, then the DRP table calculation results will appear.

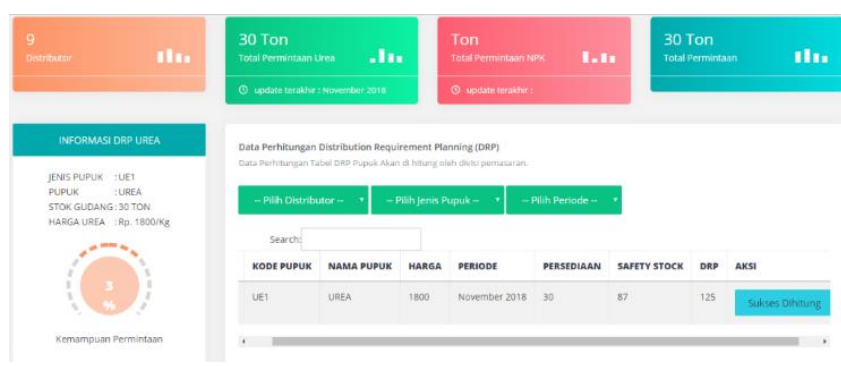

Figure 6. Display of DRP calculation

Figure 3. Display of fertilizer stock page 


\section{Fertilizer report}

The reporting page is used for management related to fertilizer processing, in this case, reports on supply, demand, fertilizer distribution, and DRP results. In the inventory report menu, it displays inventory data where the manager can also print data reports according to the selected period. Display inventory reports are shown in Figure 7.

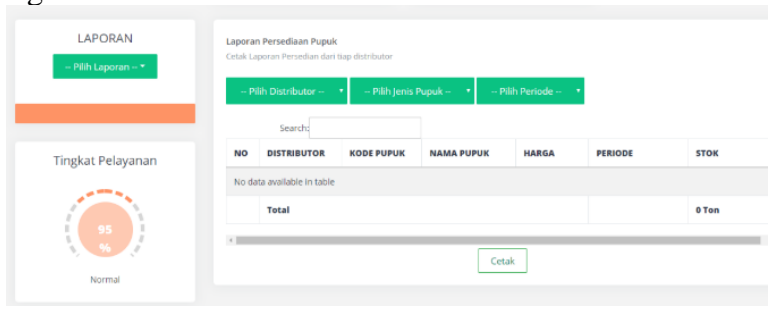

Figure 7. Display of fertilizer report

The query report function displays query data where the manager can also print query data reports according to the selected period (shown in Figure 8).

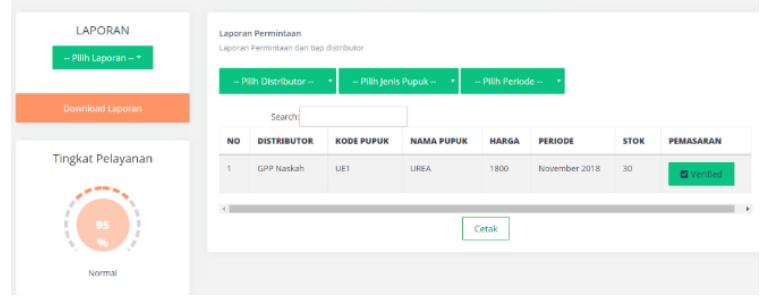

Figure 8. Display of Demand Report
Whereas the DRP report displays the DRP results table where the manager can also print data reports according to the period and type of fertilizer selected as shown in Figure 9.

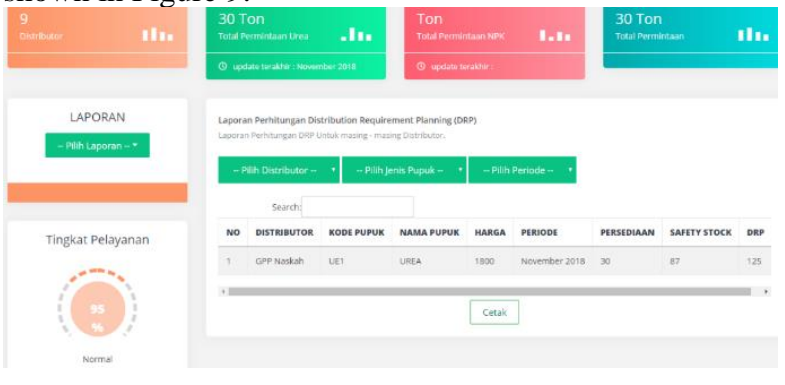

Figure 9. Display of DRP report

Table 6 shows the comparison of subsidized fertilizer management without using DRP, using DRP and using a DRP computerized system. From the table, implementation of DRP in the subsidized fertilizer data management system can optimize existing data collection and reporting functions, by adding feature requirements according to the DRP concept such as fertilizer management of stock, demand and distribution, safety stock and DRP calculation, also fertilizer report for a company manager.

Table 6. Comparison of the implementation of the DRP method in fertilizer management

\begin{tabular}{|c|c|c|c|c|}
\hline No & Management process & $\begin{array}{c}\text { Without } \\
\text { DRP }\end{array}$ & $\begin{array}{c}\text { With non } \\
\text { systematic } \\
\text { DRP }\end{array}$ & $\begin{array}{c}\text { With } \\
\text { systematic } \\
\text { DRP }\end{array}$ \\
\hline 1. & stock data collection & $\sqrt{ }$ & $\sqrt{ }$ & $\sqrt{ }$ \\
\hline 2. & demand data collection & $\sqrt{ }$ & $\sqrt{ }$ & $\sqrt{ }$ \\
\hline 3. & stock data management & $\sqrt{ }$ & $\sqrt{ }$ & $\sqrt{ }$ \\
\hline 4. & demand data management & $\sqrt{ }$ & $\sqrt{ }$ & $\sqrt{ }$ \\
\hline 5. & safety stock calculation & - & $\sqrt{ }$ & $\sqrt{ }$ \\
\hline 6. & DRP calculation & - & $\sqrt{ }$ & $\sqrt{ }$ \\
\hline 7. & stock reporting & - & - & $\sqrt{ }$ \\
\hline 8. & demand reporting & - & - & $\sqrt{ }$ \\
\hline 9. & DRP reporting & - & - & $\sqrt{ }$ \\
\hline
\end{tabular}

\section{CONCLUSION}

It can be concluded that from the implementation of the DRP method in subsidized fertilizer management system for PPD Sumsel is as follows:

1. The DRP method provides a more coordinated distribution reference for urea subsidized fertilizer. With the distribution schedule, the company can prepare everything related to product distribution activity.

2. The implementation of DRP in the subsidized fertilizer data management system is used to optimize existing data collection and reporting functions, by adding feature requirements according to the DRP concept such as fertilizer management of stock, demand and distribution, safety stock and DRP calculation, also fertilizer report for a company manager.

\section{REFERENCES}

[1] Saliem, Handewi Purwati, and Mewa Ariani. "Ketahanan pangan, konsep, pengukuran dan strategi." (2016).

[2] Suryana, Achmad. "Menuju ketahanan pangan indonesia berkelanjutan 2025: tantangan dan 
[9] Darwis, Valeriana, and Ahmad Rozany Nurmanaf. "Kebijakan Distribusi, Tingkat Harga dan Penggunaan Pupuk di Tingkat Petani." Forum Penelitian Agro Ekonomi. Vol. 22. No. 1. 2016.

[3] Ariningsih, Ening, and Handewi PS Rachman. "Strategi peningkatan ketahanan pangan rumah tangga rawan pangan." Analisis Kebijakan Pertanian 6.3 (2016): 239-255.

[4] Firdaus, Mgs Afriyan, et al. "Penyelesaian Masalah Pengelolaan Lumbung Pangan Desa Menggunakan Case-Based Reasoning dengan Algoritma K-Nearest Neighbor." Jurnal Sistem Informasi 11.1 (2019).

[5] Bowersox, Donald J., et al. "Supply Chain Logistics Management, Mc Graw Bill International Edition." New York, NY, USA (2013).

[6] Bozarth, C., and R. Handfield. "Operations and supply chain management." Strategies 21 (2008): 22.

[7] Manning, Dave. "Distribution Resource Planning is Critical in a Global Market." Logistics and Transport Focus 21.4 (2019): 51. ProQuest. Web. 10 Oct. 2019.

[8] Gaspersz, Vincent. "Production planning and inventory control." PT Gramedia Pustaka Umum, Jakarta (2004).
[10] Susila, Wayan R. "Kebijakan subsidi pupuk: ditinjau kembali." Jurnal Penelitian dan Pengembangan Pertanian 29.2 (2016).

[11] Sembiring, Nurhayati, Tuti Sarma Sinaga, and Jean Ayuningthias. "Increasing service systems in network distribution." Journal of Physics: Conference Series. Vol. 1230. No. 1. IOP Publishing, 2019.

[12] Harahap, Parlindungan, et al. "Analysis of Distribution Information System of Rice Supply Chain Management at PT. Jatisari Sri Rejeki." 3rd International Conference on Management Economics and Business of Universitas Mercu Buana (ICMEB), 21-22, 2018.

[13] Kubasakova, Iveta, Rudolf Kampf, and Ondrej Stopka. "Logistics information and communication technology." Communications-Scientific letters of the University of Zilina 16.2 (2014): 9-13. 